\title{
Modelling of rigid pavements in road projects in northern Colombia, using the Finite Element method
}

\author{
Fernando Jove Wilches*1, Carlos Millán-Páramo ${ }^{1}$ and Álvaro Rafael Caballero Guerrero ${ }^{2}$ \\ ${ }^{1}$ Department of Civil Engineering, Universidad de Sucre, Sincelejo, Sucre, Colombia. \\ ${ }^{2}$ Department of Civil and Environmental Engineering, Universidad del Norte, Barranquilla, Colombia.
}

ORCIDs: 0000-0002-2080-4036 (Fernando), 0000-0002-0004-6063 (Carlos), 0000-0002-3567-9135 (Álvaro)

\begin{abstract}
Rigid concrete pavement structure solutions are a widely used alternative worldwide. This type of flooring has serious advantages, such as its long useful life and its low level of maintenance during its service period, which nevertheless implies a high investment in the construction phase, but which is recovered over time due to its high durability. Pavement analysis and design methodologies have been based over the years on purely empirical methods. However, at present, methodologies based on mechanistic procedures are gaining popularity, with which it is intended to have a more scientific approach to the matter. However, regardless of the methodology used to carry out the design phase, a pavement project must have relevant information about the different variables involved in the performance of the structure during its service life. Therefore, it is important to have reliable information related to the characteristics of vehicular traffic, and especially, with the frequency and distribution of the loads of the heaviest vehicles; with the characteristics of the foundation soils, with the characteristics and properties of the materials that will make up the structure, and even with the climatic characteristics of the geographical area where the project will be developed. The objective pursued in this work focuses on showing the parameters involved and the results obtained in the modeling and design of rigid pavements, based on information collected from road projects located in the north of Colombia. Within the data used, the geotechnical characteristics of the subgrade soils are available, which were obtained from geotechnical studies carried out in the project area. In addition, the results of the modeling of multiple pavement structures are presented, where for different thicknesses of the concrete slab and varying the properties of the materials of the same and of the subgrade, the effect produced by the application of an external load was evaluated, consisting of a standard $80 \mathrm{kN}$ single axle with double wheel. For the modeling and analysis of the structures, the finite element method was used, through the use of the EverFE software, which is a 3D finite element analysis tool, which is commonly used to simulate the response of Jointed Plain Concrete Pavement (JPCP) in the face of traffic loads and environmental effects. Information related to the state of stresses and displacements of the pavement slabs analyzed was obtained as output data from the software.
\end{abstract}

Keywords: Pavement design, rigid pavement, material properties, subgrade, finite elements

\section{INTRODUCTION}

Pavements are multilayer road structures, that is, they are built from a set of layers stacked horizontally one on top of the other, which are designed and built with appropriate and duly compacted materials [1]. These structures rest on the subgrade and must adequately resist the stresses transmitted by traffic loads, as well as the effects generated by environmental conditions, throughout the period for which the structure has been designed [2]. The layers that make up the pavement, in addition to resisting stress and transmitting them dissipated to the subgrade, has the function of serving as a rolling surface for vehicular traffic [1].

Among the different types of existing pavement, there are those of the rigid type, which are becoming the main pavements for roads with high levels of heavy traffic, due to their long useful life and less frequent maintenance compared to flexible pavements [3]. By virtue of the above, although this type of solution requires a higher initial investment, it constitutes a viable alternative for transport systems with intensive use [4].

These pavements are road structures composed of an upper layer consisting of a hydraulic concrete slab, which is supported by a layer or several layers of granular materials or stabilized with hydraulic cementitious materials. Due to the very nature of this type of pavement (upper layer with a high modulus of elasticity, in the order of $40 \mathrm{GPa}$ ), the stresses produced by traffic are absorbed for the most part by the concrete slab, also distributing the compression stresses in a fairly wide area, causing stresses with a rather reduced magnitude [1], [5] to be transmitted to the subgrade.

In Colombia, this type of pavement is known in all regions and has been built throughout the territory, presenting a service with very good quality, for many years [6], so that the methodologies used in the analysis and design of these pavement systems, is of great importance, because it seeks to obtain optimized structures. 
New trends and the growth of technological development, such as high-performance computers, have brought methods such as 3D-FEM onto the scene. These three-dimensional finite element softwares to analyze pavements are based on a numerical approach to the analysis of displacements and stresses in structures, which are divided into smaller structures, through meshes, and their elements are connected through nodes, which makes it possible for many researchers and designers to better understand the responses of pavements under traffic loads or the environment [3]. One of these tools is the EVERFE [7] software, which is an easy-to-use 3D finite element analysis tool to simulate the response of Jointed Plain Concrete Pavement systems (JPCP) to axle loads and environmental effects.

This work shows the analysis and design of rigid pavements, obtained from several road projects located in the urban area of the municipality of Sincelejo in the department of Sucre, north of Colombia. Information related to geotechnical investigations that were carried out from field samples and laboratory tests is presented to determine the main physical and mechanical properties of the pavement foundation soils. On the other hand, the modeling of multiple pavement structures were carried out, in which the objective was to vary the thicknesses of the pavement slab, in addition to changing the properties of the materials of both the concrete slab itself and the subgrade, keeping the design load constant, which consisted of a single axle with double wheel with an load of $80 \mathrm{kN}$, which in the AASTHO methodology is considered as the standard design axle. For the modeling and analysis of the structures, the finite element method was used, through the use of the EverFE version 2.26 software.

\section{EXPERIMENTAL DESIGN, MATERIALS AND METHODS}

\section{II.I. Study area description}

The city of Sincelejo, capital of the Department of Sucre, is located in the northeast of the country at $9^{\circ} 18$ 'north latitude, $75^{\circ} 23^{\prime}$ west longitude of the Greenwich meridian; It has a total area of 28,504 hectares, with a height above sea level of 213 meters. It limits to the south with the municipality of Sampués and with the Department of Córdoba; to the west with the municipalities of Palmito and Tolú; to the north with the municipalities of Tolú and Tolú Viejo and to the east with the municipalities of Corozal and Morroa. The climate is hot dry, with an average rainfall of 500 to 1200 millimeters per year; the vegetal formation according to Holdridge is the tropical dry forest. The average annual temperature is close to $27.5^{\circ} \mathrm{C}$. A greater range is appreciated during the summer where there are marked effects caused by low temperatures in the early morning and strong heat in the afternoon. The soil of the municipality of Sincelejo is typical of the mountain landscape. It is made up of irregular and complex relief surfaces, with variable slopes and altitudes ranging from 50 to 260 meters. It includes the types of reliefs called hogbacks, bars and crests made up of calcareous sandstone and limestone materials. The municipality's hydrographic network is comprised of the micro-basins of the Grande de Corozal, Canoas, La Muerte, Mocha and San Antonio streams [8].

\section{II.II. Material and methods}

The analysis and modelling of the rigid pavement structures were carried out from several road infrastructure projects located in the city of Sincelejo, Sucre (Colombia). For this, geotechnical investigations were carried out in order to obtain the characterization of the subgrade soils, as well as their bearing capacity properties, through standardized laboratory tests. For the collection of geotechnical samples, geotechnical surveys were made manually to a depth of 1.50 meters. The samples were transported to the laboratory and the soil classification was carried out through the Unified Soil Classification System (USCS) and the AASHTO Soil Classification System [9], based on the results of the particle size analysis of soils tests [10] and the tests to determine the Atterberg limits [11]. Then, to determine the bearing capacity of the soil, the California Bearing Ratio (CBR) [12] laboratory test was carried out, based on undisturbed samples cured by immersion for 4 days.

On the other hand, it proceeded to characterize the Granular Base materials and the concretes used to model the rigid pavement slabs. In the case of the granular base, materials were evaluated according to the material specifications of the Instituto Nacional de Vías (INVIAS) [13], thus obtaining materials with all the requirements issued by said specifications and emphasizing obtaining a material with a higher CBR to $80 \%$. In the case of concrete used as pavement slab, tests were carried out on concrete samples according to the INVIAS test standards, compressive strength of cylindrical concrete specimens tests [14] and flexural strength concrete were made (simple beam loads in thirds of the span) [15], all this in order to obtain the strength properties of concrete and to be able to correlate them with its Modulus of Rupture and its Modulus of Elasticity.

After characterizing the materials to be used in the analysis and modelling, the determination of the reference load was followed, which consisted of a simple double wheel axle with a total weight of $80 \mathrm{kN}$, which is categorized by the AASTHO as an equivalent single axle load [16].

In the case of the Modulus of Elasticity and the Poisson's Ratio of the Subgrade and the Base, the recommendations established in the document "Subbase and subgrade performance investigation and design guidelines for concrete pavement" [17] were followed. In the case of concrete, to estimate these parameters, the recommendations set forth in the document "Properties of Concrete for Use in Eurocode 2" [18] were adopted. From all the variables considered, the values reported in Table 1 could be obtained.

Once all the design variables had been defined, the modelling began. The typical sections of the modelled pavements were made up of a concrete slab, followed by a granular base, and finally, a layer of selected soils to improve the characteristics of the subgrade soils. For the generation of the model geometry, 
International Journal of Engineering Research and Technology. ISSN 0974-3154, Volume 13, Number 11 (2020), pp. $3970-3976$

(C) International Research Publication House. https://dx.doi.org/10.37624/IJERT/13.11.2020.3970-3976

square slabs of 3 meters by 3 meters were used, which were meshed every $25 \mathrm{~cm}$ in plan and three divisions were made in the direction of the layers of the structure. For the modelling of the structures, the following combination of factors was taken into account: 3 modulus of elasticity of the concrete, 3 modulus of subgrade reaction, and 21 thicknesses of the slab, which generated a total of 189 runs through the software based on finite elements EverFE 2.26. From the modelling, it was possible to determine the results of efforts in the paving slabs (Fig. 2), as well as the displacements of the structure. With the information obtained, figures were constructed and a dataset was generated using the Excel spreadsheet tool.'

\section{RESULTS}

The figures and tables presented in this article were made from the modeling of 189 rigid pavement structures. These structures were analyzed based on the information from the characterization of the subgrade soils and granular materials, obtained from samples taken in the field and tested in the laboratory. The pavement structures modeled and analyzed correspond to road infrastructure solutions carried out for different projects developed in the city of Sincelejo, Sucre (Colombia).

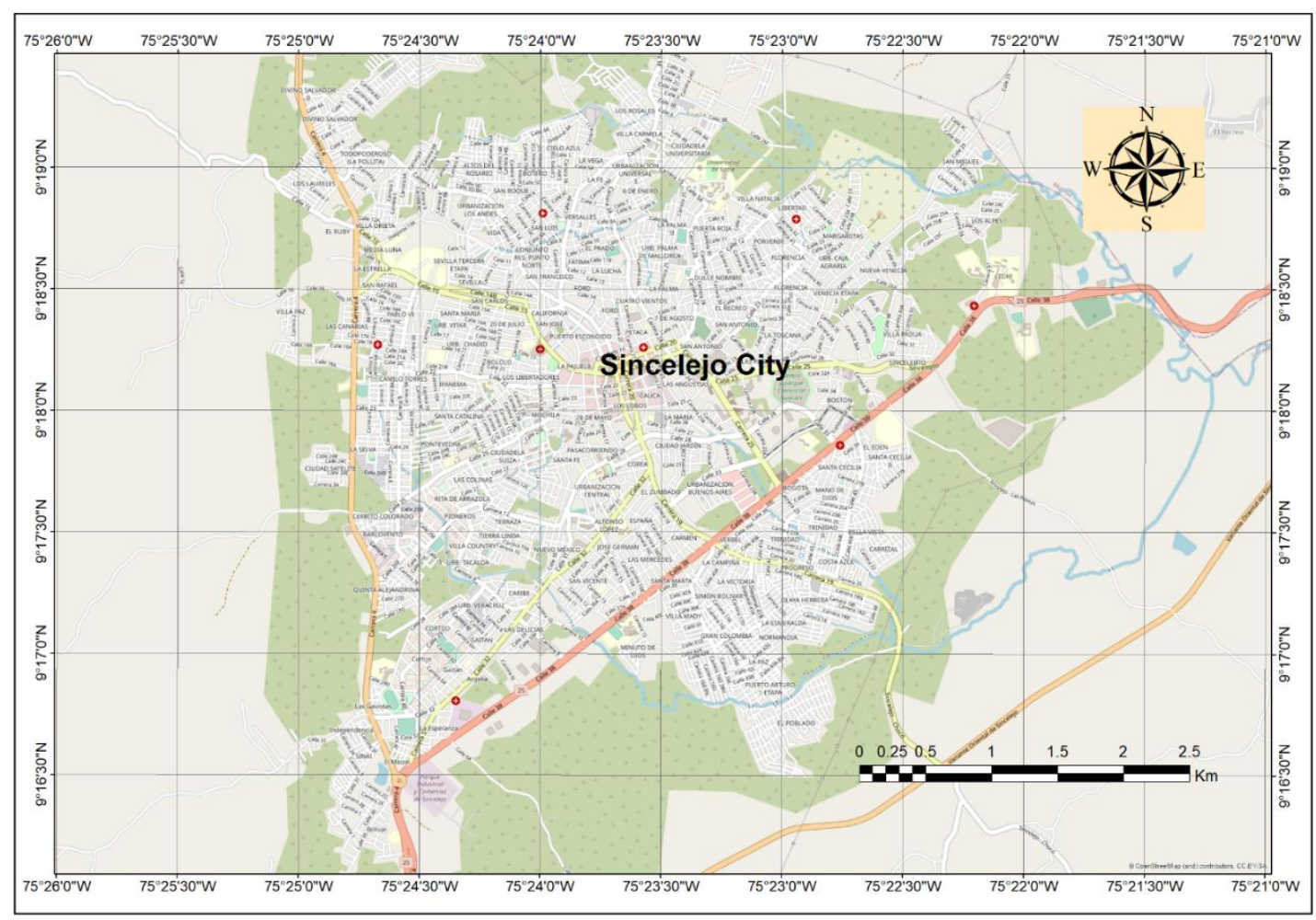

Fig. 1. Location of the city of Sincelejo (research area)

Table 1. Summary of input data from the modeling

\begin{tabular}{ccc}
\hline Variable & Material & Value \\
\hline \multirow{3}{*}{ California Bearing Ratio } & Clayey Subgrade & 1.2 \\
$(\mathrm{CBR}, \%)$ & Granular Subgrade & 10 \\
& Improved subgrade Soil & $3.0,5.0$ \\
& Granular Base & 80 \\
\hline \multirow{2}{*}{ Layer Thickness $(\mathrm{mm})$} & Concrete Slab & $100-300$ in increments of 10 to $10 \mathrm{~mm}$ \\
& Granular Base & 200 \\
& Selected Soils & $150,200,300$ \\
\hline \multirow{3}{*}{ Young's Modulus (Mpa) } & Concrete Slab & $28000,30000,32000$ \\
& Granular Base & 200 \\
& Selected Soils & $30,50,100$ \\
\hline \multirow{2}{*}{ Poisson's Ratio } & Concrete Slab & 0.20 \\
& Granular Base & 0.40 \\
& Selected Soils & 0.45 \\
\hline
\end{tabular}


International Journal of Engineering Research and Technology. ISSN 0974-3154, Volume 13, Number 11 (2020), pp. 3970-3976

(C) International Research Publication House. https://dx.doi.org/10.37624/IJERT/13.11.2020.3970-3976

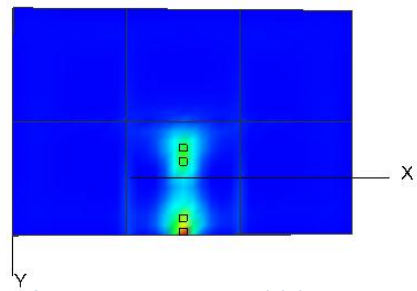

Slab Thickness $=100 \mathrm{~mm}$

Max Principal Stress
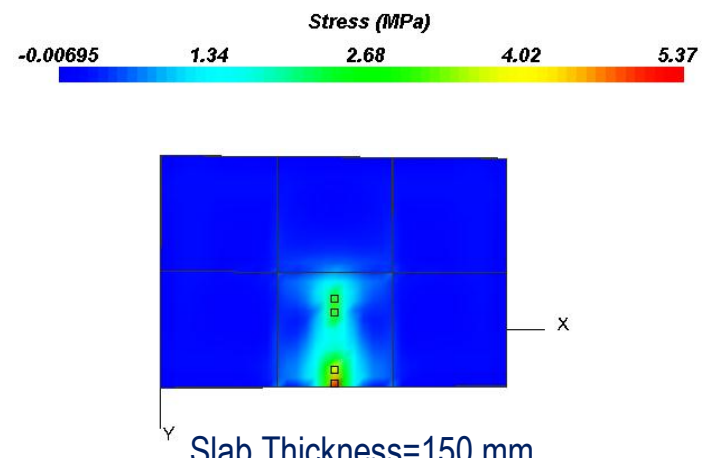

Max Principal Stress
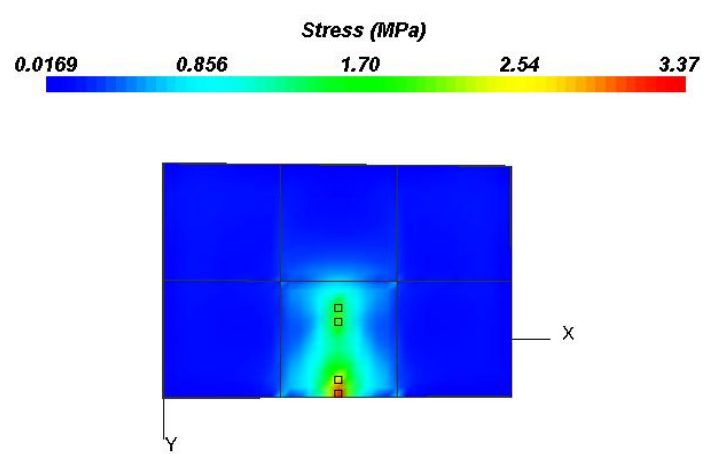

Slab Thickness $=200 \mathrm{~mm}$

Max Principal Stress

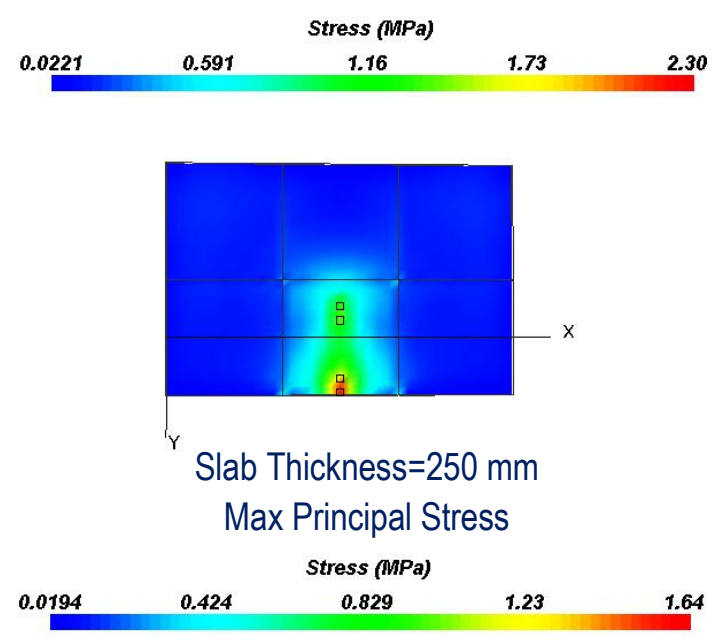

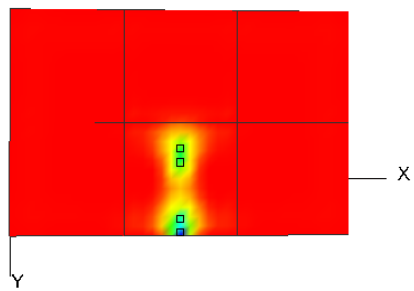

Slab Thickness $=100 \mathrm{~mm}$

Min Principal Stress

Stress (MPa)
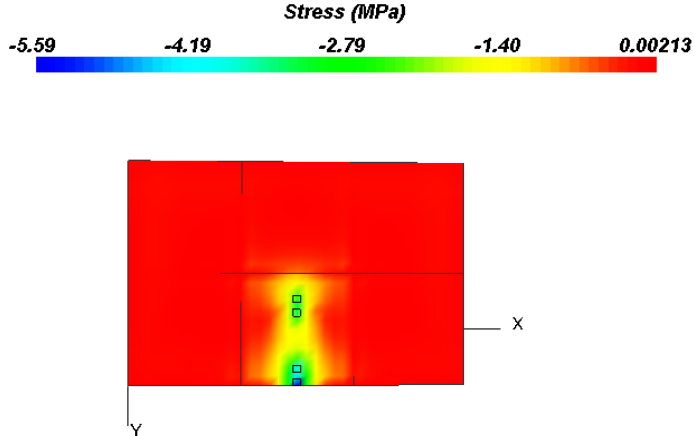

Slab Thickness $=150 \mathrm{~mm}$

Min Principal Stress
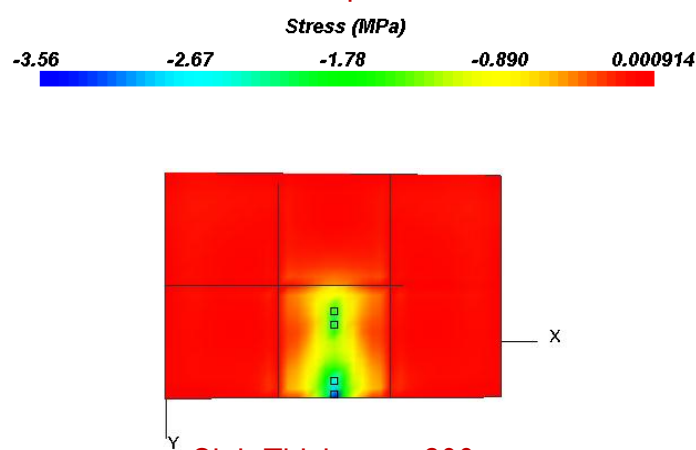

Slab Thickness $=200 \mathrm{~mm}$

Min Principal Stress
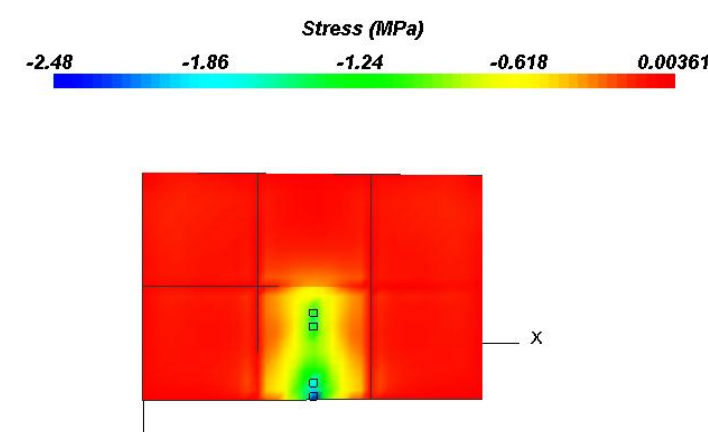

Slab Thickness $=250 \mathrm{~mm}$

Min Principal Stress

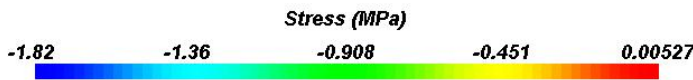

Fig. 2. Distribution of principal compressive and tensile stresses of the modeled pavement system, generated through the EverFE 2.26 software 
In Fig. 1, the location of the city of Sincelejo and its road network system are shown. Table 1 presents the input data required to perform the modeling of the rigid pavement structures.

Fig. 2 shows the results of the maximum and minimum principal stresses, generated by the EverFE v2.26 finite element software, for the different pavement structures. The results of the structures with a concrete slab thickness of 100, 150, 200 and $250 \mathrm{~mm}$ are presented, for a modulus of elasticity of the Concrete of $28,000 \mathrm{MPa}$, as well as modulus of Elasticity for the Granular Base of $200 \mathrm{MPa}$ and for the improved subgrade of $50 \mathrm{MPa}$.
Fig. 3 shows the maximum principal stresses in the paving slab as a function of the Modulus of Elasticity of the Concrete and Fig. 4 shows the maximum and minimum stress in the rigid concrete slab.

In Fig. 5 the maximum principal stresses that occur in the different thicknesses of the concrete slabs for the bearing capacities of the evaluated subgrade are presented $(\mathrm{CBR}=3,5$ and $10 \%$ ) and in Fig. 6 it is shown the results of the displacements in $\mathrm{Z}$ of the structures modeled on the basis of the CBR values of the soils of the subgrade.

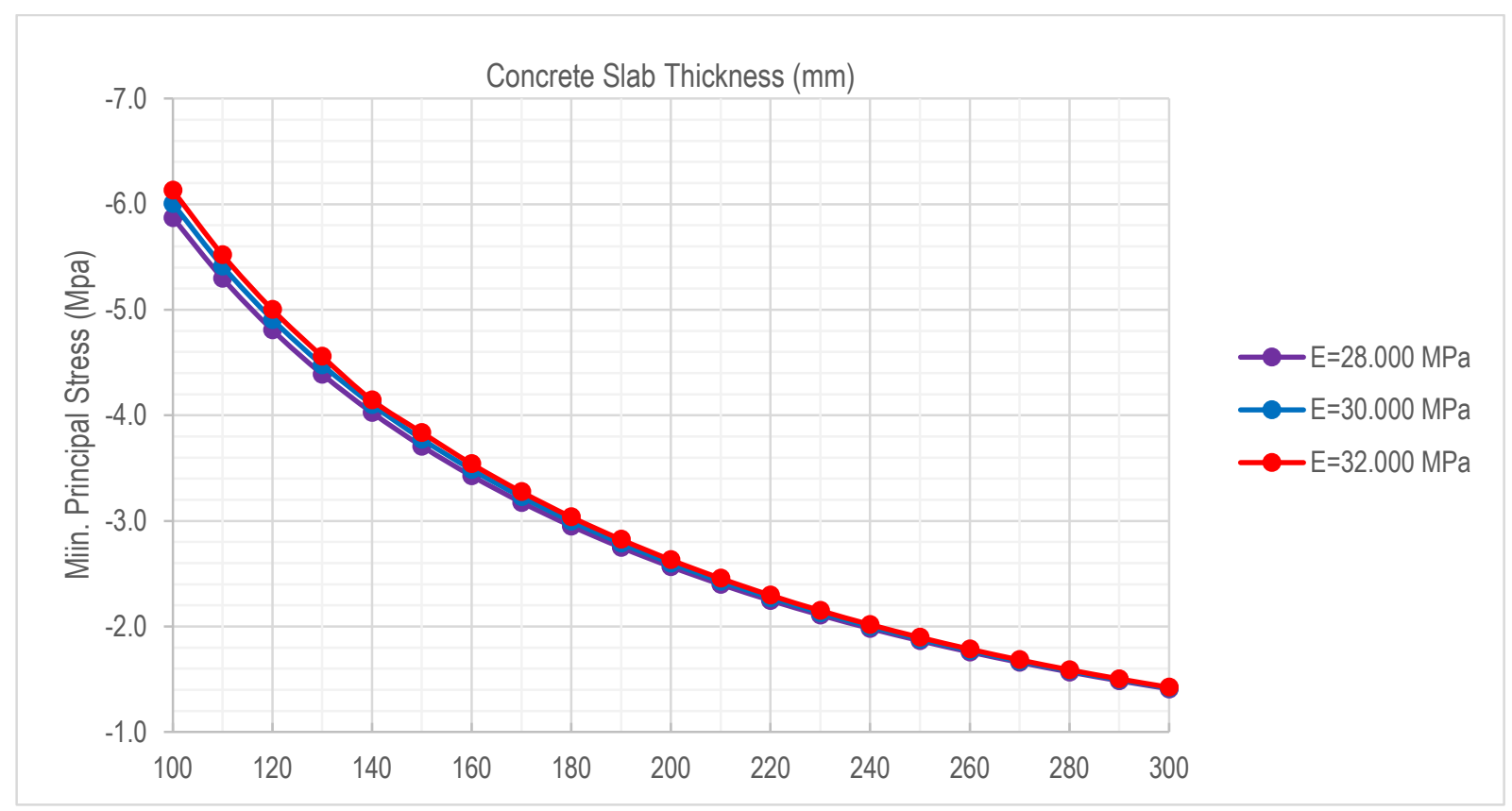

Fig. 3. Principal tensile stresses in the concrete slab

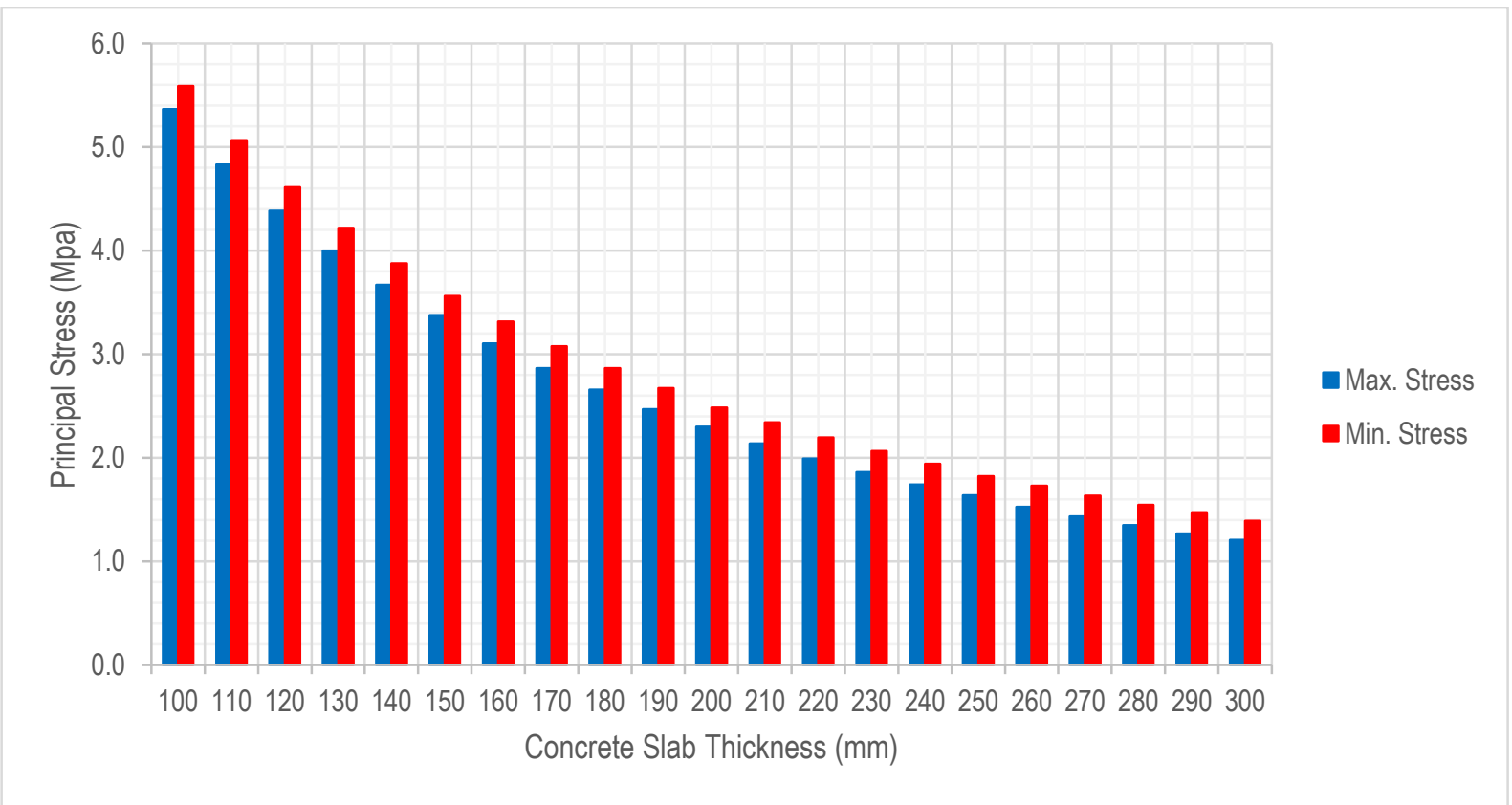

Fig. 4. Values of minimum principal stress (tensile stress) and maximum principal stress (compressive stress) in the paving concrete slab 


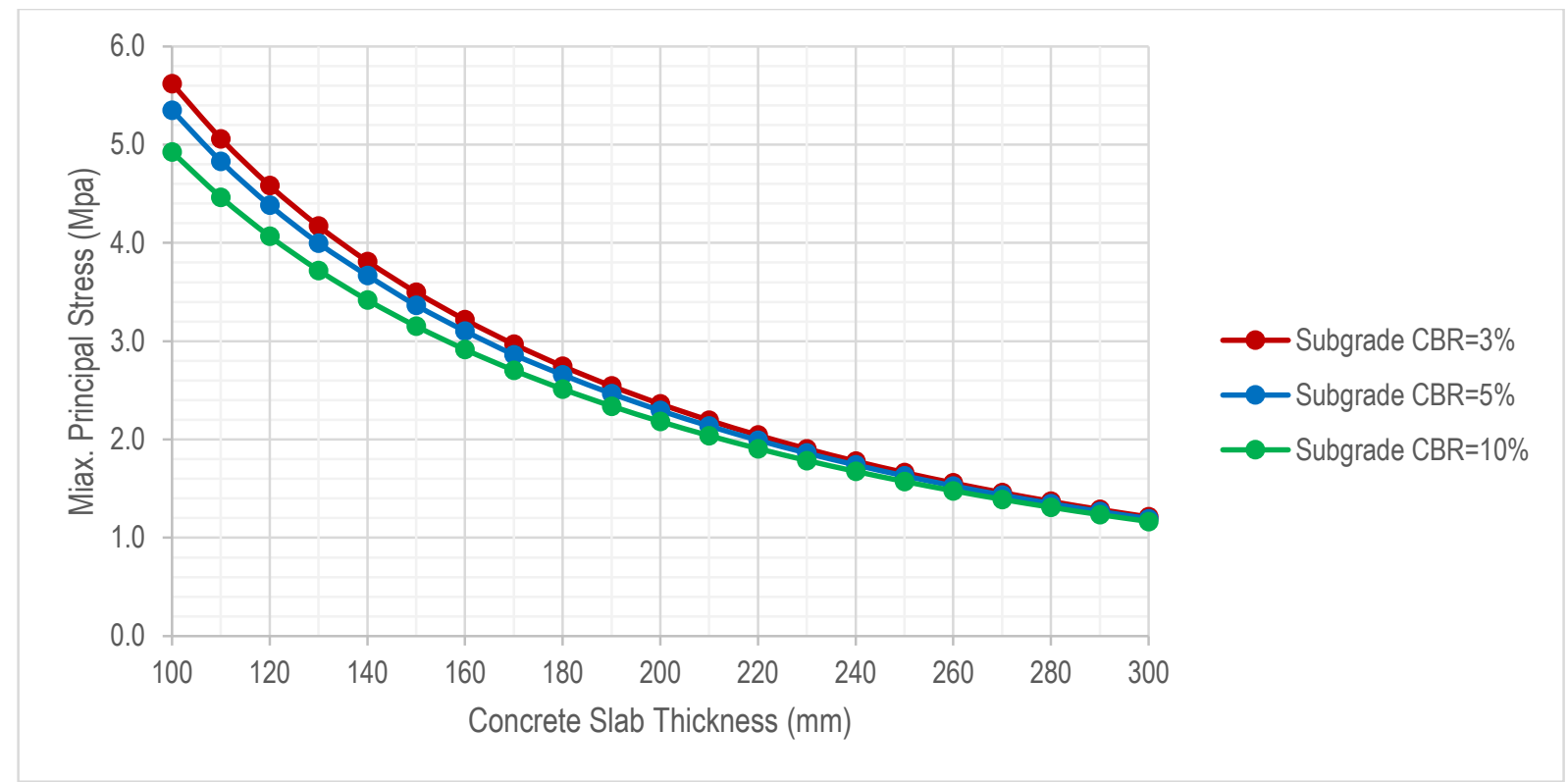

Fig. 5. Maximum principal stresses of the paving slab

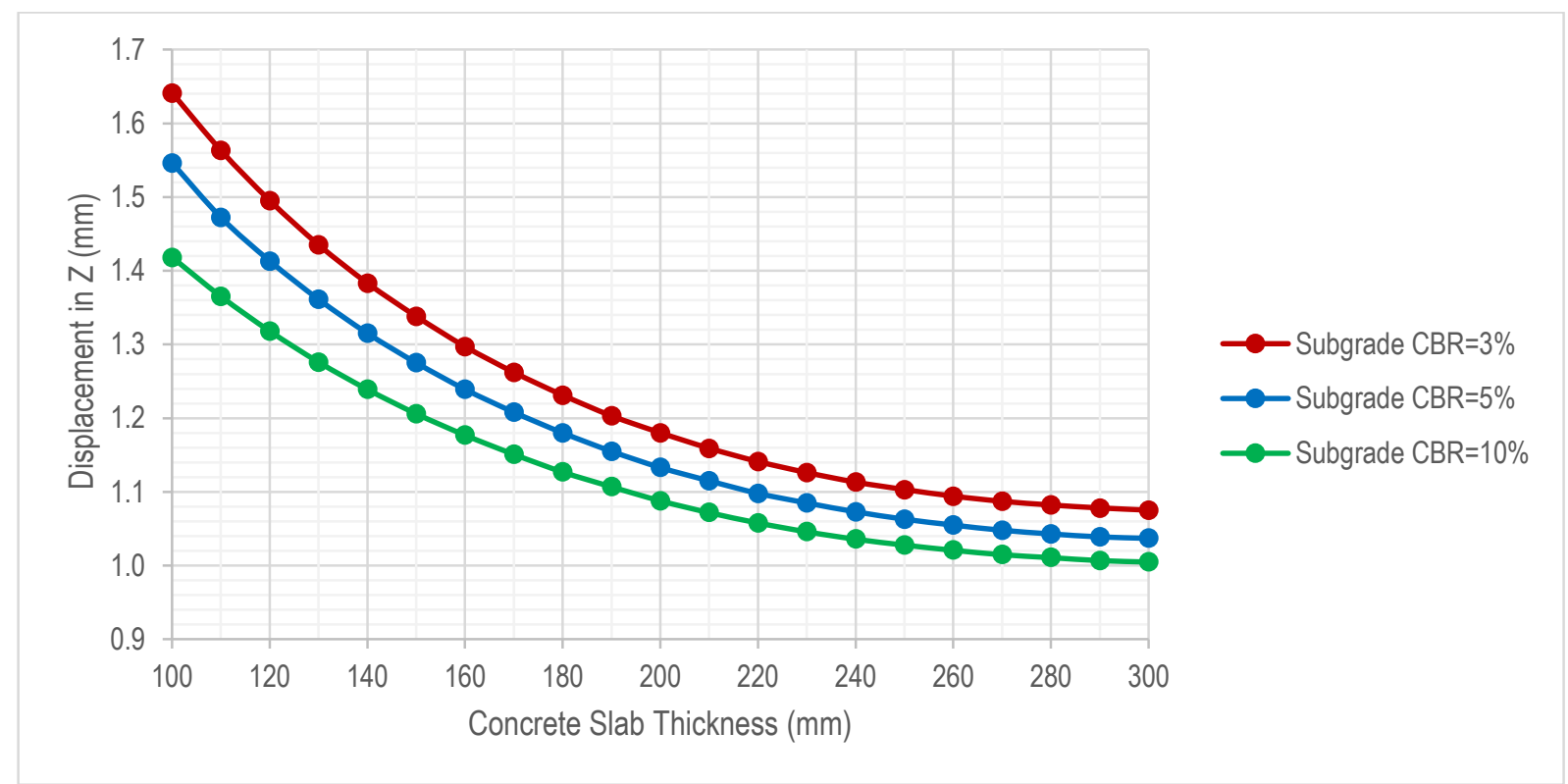

Fig. 6. Displacements in $\mathrm{Z}$ of the concrete slab

\section{CONCLUSIONS}

From the results obtained in the present work, it can be concluded:

Regarding the modulus of elasticity of the concrete slab, it is observed that for the different modules analyzed 28, 30 and 32 $\mathrm{GPa}$, the main stresses produced in the pavement slabs were practically the same.

Regarding the main tensile and compression forces generated in the pavement slabs, it could be observed that as the thickness increased, lower concentrations were generated in the forces transmitted to the granular support layers. This is graphically evidenced in the outputs of the finite element software, where it was observed that for greater thicknesses, the pressures are distributed in a larger area.
On the other hand, it was observed that as the bearing capacity of the subgrade increases, the stresses generated in the slabs tend to decrease somewhat. The differences found were not so significant, especially in the case of slab thicknesses greater than $20 \mathrm{~cm}$.

With respect to vertical displacements, as the bearing capacity of the subgrade increases, the vertical deflections generated tend to decrease, for the same slab thickness.

\section{ACKNOWLEDGMENTS}

The authors thank the engineer Edilberto Elias Contreras Sierra for the contributions made in the development of the manuscript. 


\section{REFERENCES}

[1] Rondón H, Reyes F, Pavimentos: Materiales, construcción y diseño. Primera edición. Ecoe Ediciones, Bogotá, 2015.

[2] Montejo A, Ingeniería de Pavimentos: Fundamentos, estudios básicos y diseño, Segunda Edición, Universidad Católica de Colombia, Bogotá, 1998.

[3] Shaban A, Alsabbagh A, Wtaife S, Suksawang N, Effect of Pavement Foundation Materials on Rigid Pavement Response. IOP Conference Series: Materials Science and Engineering, 671, 2020. Doi: https://doi.org/10.1088/ 1757-899X/671/1/012085

[4] Kim S, Early age behavior of jointed plain concrete pavements subjected to environmental loads, $\mathrm{PhD}$ dissertation, Iowa State University, Iowa, 2007. Doi: https://doi.org/10.31274/rtd-180813-11649

[5] Reyes F, Diseño racional de pavimentos, Primera Edición, CEJA, Bogotá, 2003.

[6] Londoño C, Álvarez J, Manual de diseño de pavimentos de concreto: para vías con bajos, medios y altos volúmenes de tránsito, Instituto Colombiano de Productores de Cemento ICPC, Medellín, 2008.

[7] Davids WG, Mahoney JP. Experimental verification of rigid pavement joint load transfer modeling with EverFE. Transportation Research Record, 1684(1), 81-89 1999.

[8] Concejo de Sincelejo, Plan de Desarrollo - Municipio de Sincelejo 2020 - 2023. https://concejosincelejo. micolombiadigital.gov.co/sites/concejosincelejo/content/ files/000173/8602_pdm-sincelejo-2020-2023-unidostransformamos-mas.pdf, 2020 (accessed 5 October 2020).

[9] University of Massachusetts Lowell, SOIL MECHANICS - Soil Classification. http://faculty.uml. edu/ehajduk/Teaching/14.330/documents/14.330SoilCla ssification.pdf, 2015 (accessed 5 October 2020).

[10] ASTM D6913 / D6913M-17, Standard Test Methods for Particle-Size Distribution (Gradation) of Soils Using Sieve Analysis, ASTM International, West Conshohocken, PA, 2017, DOI: 10.1520/D6913_D6913M-17.

[11] ASTM D4318-17e1, Standard Test Methods for Liquid Limit, Plastic Limit, and Plasticity Index of Soils, ASTM International, West Conshohocken, PA, 2017, DOI: 10.1520/D4318-17E01.

[12] AASHTO T 193, The California Bearing Ratio, Standard Specifications for Transportation Materials and Methods of Sampling and Testing, Thirty-Third Edition. American Association of State Highway and Transportation Officials. Washington, D.C., 2013.

[13] Ministerio de Transporte, Normas y Especificaciones 2012 INVIAS, Instituto Nacional de Vías, Bogotá, D.C., 2013.

[14] ASTM C39 / C39M-17, Standard Test Method for Compressive Strength of Cylindrical Concrete Specimens, ASTM International, West Conshohocken, PA, 2017, DOI: 10.1520/C0039_C0039M-17.
[15] ASTM C78 / C78M-18, Standard Test Method for Flexural Strength of Concrete (Using Simple Beam with Third-Point Loading), ASTM International, West Conshohocken, PA, 2018, DOI: 10.1520/C0078_C0078M-18.

[16] American Association of State Highway and Transportation Officials, AASHTO Guide for Design of Pavement Structures, Washington, D.C., 1993.

[17] Texas Department of Transportation, Subbase and subgrade performance investigation and design guidelines for concrete pavement. https://static.tti.tamu. edu/tti.tamu.edu/documents/0-6037-2.pdf, 2012 (accessed 28 September 2020).

[18] Bamforth P, Chisholm D, Gibbs J, Harrison T, Properties of Concrete for Use in Eurocode 2: How to Optimise the Engineering Properties of Concrete in Design to Eurocode 2, MPA The Concrete Centre, United Kingdom, 2008. 